\title{
EVALUATION OF THE RANGE OF MOTION OF A HIP ARTHROPLASTY SYSTEM: A COMPUTER SIMULATION STUDY
}

\author{
AVALIAÇÃO DA AMPLITUDE DE MOVIMENTO DE \\ UM SISTEMA ARTROPLÁSTICO DO QUADRIL: \\ ESTUDO POR SIMULAÇÃO COMPUTACIONAL
}

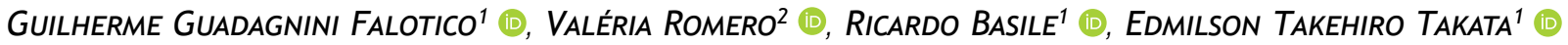 \\ 1. Universidade Federal de São Paulo, São Paulo, SP, Brazil. \\ 2. Universidade Estadual de Campinas, Campinas, SP, Brazil.
}

\section{ABSTRACT}

Objective: To date, the literature lacks consensus on the most efficient method to measure the range of motion of an in vitro prosthetic system. In this study, we propose the use of a relatively low-cost online software to measure the range of motion of hip prosthetic implants manufactured in Brazil and compare its results with the current technical standards for hip arthroplasty. Methods: Three different diameters of femoral heads were evaluated $(28 \mathrm{~mm}, 32 \mathrm{~mm}$, and $36 \mathrm{~mm}$ ). The mean values of the angular displacement of the prosthesis in each motion axis were obtained by computer simulations. Results: The range of motion with each femoral head was $28 \mathrm{~mm}$ (extension/flexion: $148^{\circ}$, internal/external rotation: $179^{\circ}$, adduction/abduction: $107^{\circ}$ ), $32 \mathrm{~mm}\left(152^{\circ} / 185^{\circ} / 114^{\circ}\right)$, and $36 \mathrm{~mm}\left(158^{\circ} / 193^{\circ} / 120^{\circ}\right)$. Conclusion: The computational method showed that the larger the femoral head, the greater the range of motion of the hip joint prosthetic system. Additional clinical studies are necessary to compare the physical results obtained with the values found in this study by computational modeling. Level of evidence $V$, Experimental study.

Keywords: Range of Motion, Articular. Total Hip Arthroplasty. Hip Prosthesis.

\begin{abstract}
RESUMO
Objetivo: A maneira mais eficiente de se aferir a amplitude de movimento de um sistema protético in vitro ainda não é bem estabelecido na literatura. Assim, o presente estudo propõe a utilização de um software online de custo relativamente baixo para mensuração da amplitude de movimento de um conjunto protético nacional de quadril e comparar os resultados obtidos com a norma técnica vigente para as artroplastias de quadril. Métodos: A avaliação foi realizada com três diferentes diâmetros de cabeças femorais $(28 \mathrm{~mm}, 32 \mathrm{~mm}$ e $36 \mathrm{~mm}) ;$ os valores médios do deslocamento angular da prótese em cada eixo de movimento foram obtidos por meio de simulações computacionais no programa Autodesk Inventor. Resultados: as amplitudes de movimento obtidas foram: cabeça 28mm (extensão/ flexão: $148^{\circ}$, rotação interna/externa: $179^{\circ}$, adução/abdução: $107^{\circ}$ ), cabeça $32^{\circ}\left(152^{\circ} / 185^{\circ} / 114^{\circ}\right)$, cabeça $36^{\circ}\left(158^{\circ} / 193^{\circ} / 120^{\circ}\right)$. Conclusão: O método computacional utilizado no presente estudo possibilitou concluir que quanto maior a cabeça femoral, maior será a amplitude de movimento do sistema protético para articulação de quadril. Novos estudos clínicos, tanto pré quanto pós-operatórios, devem ser realizados para comparar os resultados físicos obtidos com os valores encontrados nesta avaliação por meio de modelo computacional. Nível de Evidência V, Estudo experimental.
\end{abstract}

Descritores: Amplitude de Movimento Articular. Artroplastia Total de Quadril. Prótese de Quadril.

Citation: Falotico GG, Romero V, Basile R, Takata ET. Evaluation of the range of motion of a hip arthroplasty system: a computer simulation study. Acta Ortop Bras. [online]. 2021;29(5):246-248. Available from URL: http://www.scielo.br/aob.

\section{INTRODUCTION}

Prosthetic instability is one of the main indications for hip revision surgery, representing approximately $21 \%$ of revision surgical procedures. ${ }^{1}$ In addition, acetabular malposition is recognized as the main factor for prosthetic dislocation. However, dislocation episodes occur even when hip arthroplasties are placed in the Lewinnek safe zone. ${ }^{2}$ The impingement between the femoral and acetabulum components is an important mechanism causing dislocation in supposedly well-positioned prostheses. Marchetti et al. demonstrated in a clinical study of prostheses that underwent revision that $80 \%$ of the prostheses removed due to instability had macroscopic signs of impingement between the prosthetic elements. ${ }^{3}$ Contact between components is also related to wear, loosening, and early failure of arthroplasty. ${ }^{4}$ Thus, the construction of a prosthetic hip without impact between its components is essential for the long-term success of the surgery.

All authors declare no potential conflict of interest related to this article.

The study was conducted at Departamento de Ortopedia e Traumatologia da Universidade Federal de São Paulo.

Correspondence: Guilherme Guadagnini Falotico. Rua Napoleão de Barros, 715, Vila Clementino, São Paulo, SP, Brazil, 04024002. ggfalotico@yahoo.com.br 
To obtain an impingement-free arthroplasty, besides the good positioning of the components, an increase in the range of motion of the prosthetic system must be sought. This is most commonly achieved by increasing the diameter of the prosthetic femoral head $(>28 \mathrm{~mm}) .{ }^{5}$ However, the most efficient way to measure the range of motion of a prosthetic system is not well established in the literature. ${ }^{6-8}$

In this study, we propose the use of a simple and relatively low-cost online software to measure the range of motion of a hip prosthetic manufactured in Brazil and compare the results obtained with the values established by the regulations for hip prosthetic implants. ${ }^{9}$

\section{MATERIALS AND METHODS}

The evaluation was performed with Taper femoral prosthesis and Phenom Poly II acetabulum (Víncula, Brazil) with three different femoral head diameters $(28 \mathrm{~mm}, 32 \mathrm{~mm}$, and $36 \mathrm{~mm})$; the mean values of the angular displacement of the prosthesis in each axis of movement (flexion/extension, abduction/adduction, and internal/external rotation) (Figures 1, 2, and 3) were obtained through computer simulations in the Autodesk Inventor ${ }^{\circledR}$ software. All evaluation parameters were based on the normative document "ISO 21535:2007 Non-active surgical implants - Joint replacement implants - Specific requirements for hip-joint replacement implants". ${ }^{9}$ We limited the movements to simulate the collision between the components. We analyzed the overlaps using the software solver called Contact Set, making sure that all components were within the limits pre-established by the technical standard for prosthetic implants.

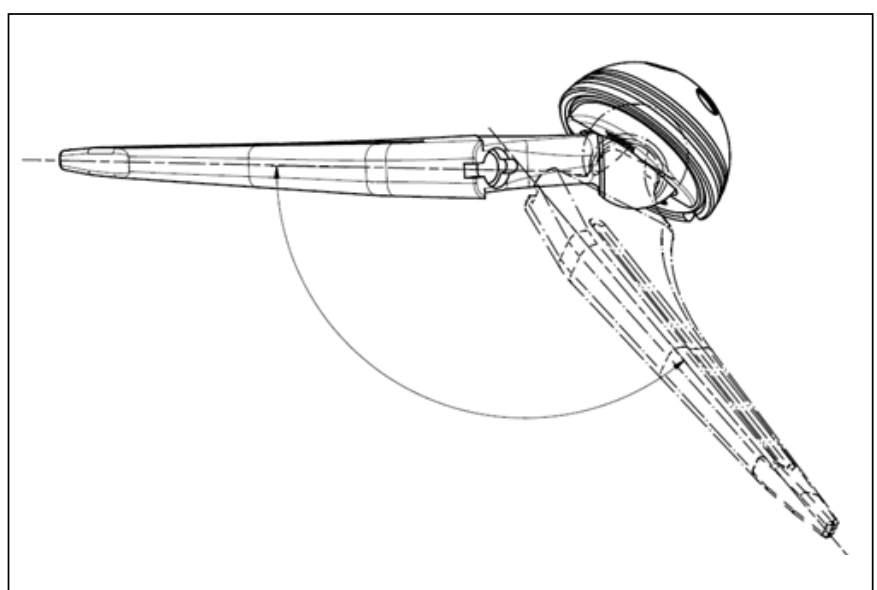

Figure 1. Flexion/Extension Movement.

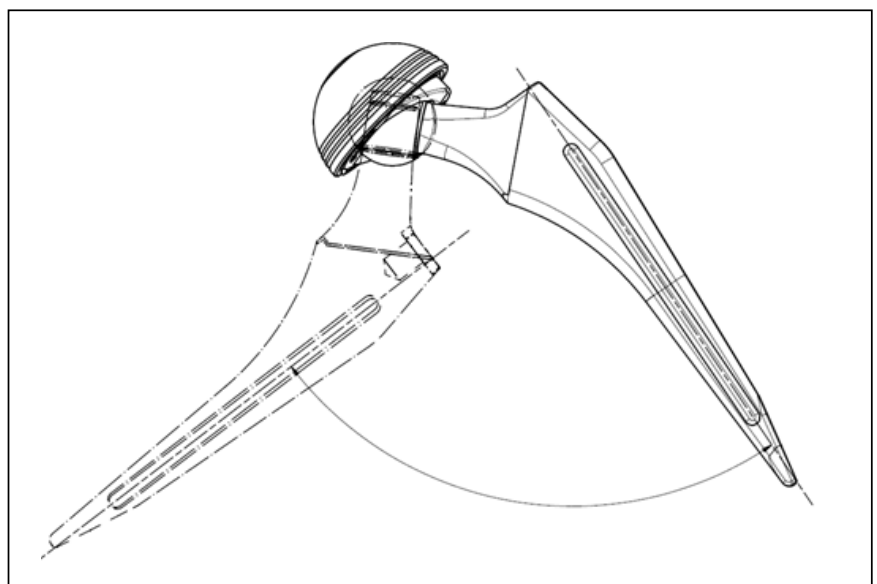

Figure 2. Abduction/Adduction Movement.

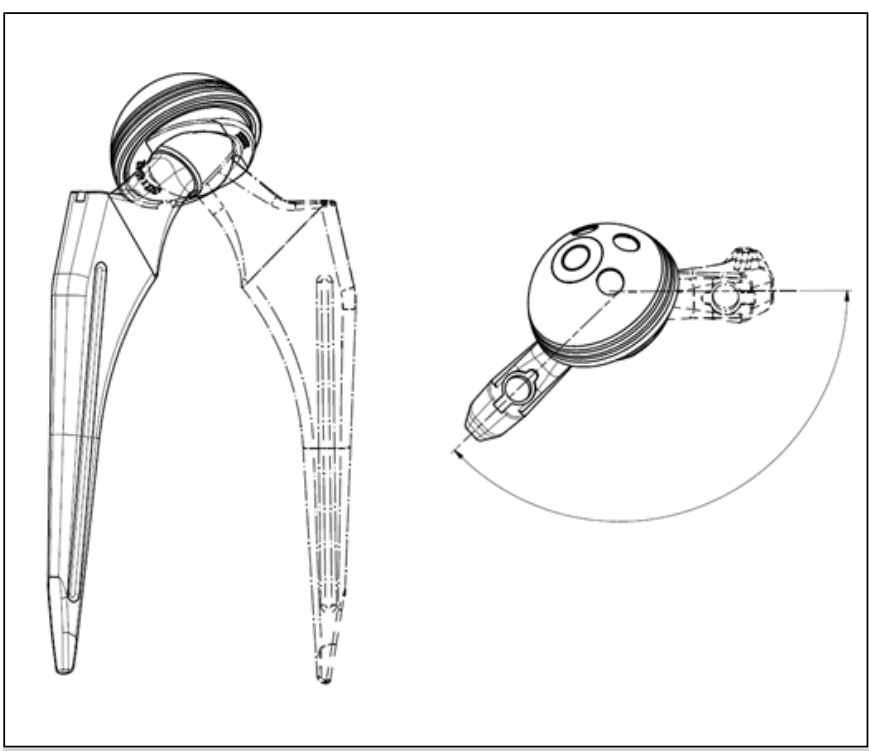

Figure 3. Internal/External Rotation Movement.

We simulated the components under the "worst-case" scenario, in which the smallest ranges of motion are recorded. The criterion for choosing the prosthetic was based on a geometric evaluation of the system; different sizes of femoral heads were included and combined with a polyethylene acetabular insert with a $10^{\circ}$ edge, as this insert has the shortest impingement-free angular path.

The implants were positioned according to the Lewinnek safe zone ${ }^{10}$ described as follows:

- The acetabulum is positioned at $45^{\circ}$ to the sagittal plane and $15^{\circ}$ to the frontal plane;

- The femoral component performed the simulations in the 3 planes of motion.

Following ISO 21535 , of $2008,{ }^{11}$ the values that define adequate prosthetic functioning must be greater than or equal to the following total arc of motions: $100^{\circ}$ for flexion/extension movements; $60^{\circ}$ for abduction/adduction movements, and $90^{\circ}$ for internal/ external rotation.

\section{RESULTS}

The different diameters of the femoral heads observed in the range of motion assessment tests for the Brazilian prosthetic system for the hip joint were: head $28 \mathrm{~mm}$ (extension/flexion: 148 ${ }^{\circ}$, internal/external rotation: $179^{\circ}$, adduction/abduction: $107^{\circ}$ ), head $32^{\circ}$ (extension/ flexion: $152^{\circ}$, internal/external rotation: $185^{\circ}$, adduction/abduction: $114^{\circ}$ ), head $36^{\circ}$ (extension/flexion: $158^{\circ}$, internal/external rotation: $193^{\circ}$, adduction/ abduction: $120^{\circ}$ ) (Table 1).

Table 1. Comparison of the different diameters of the femoral heads observed in the hip prostheses ranges of motion assessment tests and normative values.

\begin{tabular}{|c|c|c|c|c|}
\hline Movements & 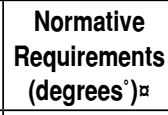 & $\begin{array}{c}28^{\circ} \mathrm{mm} \text { head } \\
p=0.023\end{array}$ & $\begin{array}{c}32^{\circ} \mathrm{mm} \text { head } \\
p=0.020 \alpha\end{array}$ & $\begin{array}{c}36^{\circ} \mathrm{mm} \text { head } \\
p=0.018\end{array}$ \\
\hline $\begin{array}{c}\text { Flexion/ } \\
\text { Extension } \times\end{array}$ & $100^{\circ}$ & $148^{\circ}$ & $152^{\circ} a$ & $158^{\circ}$ \\
\hline $\begin{array}{l}\text { Abduction/ } \\
\text { Adduction }\end{array}$ & $60^{\circ}$ & $107^{\circ}$ & $114^{\circ} x$ & $120^{\circ} x$ \\
\hline $\begin{array}{c}\text { Internal/ } \\
\text { External } \\
\text { Rotation } ם\end{array}$ & $90^{\circ} \square$ & $179^{\circ}$ & $185^{\circ}$ & $193^{\circ} x$ \\
\hline
\end{tabular}


We found a statistically significant difference in the range of motion of the prosthesis with a $28 \mathrm{~mm}$ head compared to the set with a 32 $\mathrm{mm}$ head $(p=0.011)$, in the analysis of $28 \times 36 \mathrm{~mm}(p=0.004)$ and $32 \times 36 \mathrm{~mm}(\mathrm{p}=0.004)$.

Paired values were compared using Student's t-test, considering a $5 \%$ significance level.

\section{DISCUSSION}

The results obtained through computational analysis in the Autodesk Inventor ${ }^{\circledR}$ software are compatible with other evaluation methods of the prosthetic range of motion described in the literature. In addition, the angulation values were higher when compared to the range of motion values established by the normative instruction "ISO/ABNT 21535:2018" (extension/flexion: 100', internal/external rotation: $90^{\circ}$, adduction/abduction: $60^{\circ}$ ). Thus, the use of a simple and relatively low-cost online tool can be applied in clinical practice in patients in the postoperative period of total hip arthroplasty for a range of hip movements, as well as in the preoperative period to find the best positioning of the prosthesis for each patient.

In 2008, Kiguchi et al. ${ }^{12}$ evaluated the dislocation of a prosthetic system using a hip movement simulator with 26,32 , and $40 \mathrm{~mm}$ heads and concluded that uncoupling occurred earlier with 26 $\mathrm{mm}$ heads. However, this experimental study performed only a descriptive analysis of the angle values. ${ }^{12}$

Bunn, Colwell Jr and D'Lima ${ }^{13}$ in 2014 developed a computer model based on tomographic images to assess the influence of the diameter of the prosthetic femoral head on the risk of postoperative dislocation and concluded that the risk of impingement and dislocation was lower for larger heads. The disadvantage of the method is the need to expose the patient to radiation to capture the images. ${ }^{13}$

McCarthy et al. ${ }^{14}$ in 2016 analyzed 10 patients in flexion positions considered to be at risk for posterior hip dislocation (standing from a low chair, and squatting and picking up an object on the ground). Movement markers were placed in the anterosuperior iliac spine and sacrum and the movement of the femur in relation to the pelvis was recorded (flexion-extension, adduction-abduction, and medial and lateral rotation). The results were extrapolated for computational biomechanical analysis and all components were within the prosthetic Lewinnek's safe zone. During the squat, 8 out of 10 prosthetic hips had impingement, and impingement occurred in 9 of the 10 prostheses when picking up an object on the ground. All patients had a $36 \mathrm{~mm}$ femoral head. Thus, the study concluded that even with a larger diameter femoral head and the prosthesis in a safe zone, extreme amplitude activities can lead to prosthetic impact and increase the dislocation risk. ${ }^{14}$

Gu et.al. ${ }^{15}$ in 2019 developed an impact analytical model to establish the ideal specific positioning of the prosthesis for each patient during the preoperative period. The model was created through mathematical calculations and associated computer simulation and allows to demonstrate the impact-free areas (green) and the risk areas (red) with an accuracy of $\pm 1.4^{\circ} .15$ Despite being very promising, its clinical applicability is not feasible due to its high cost and lack of access to this system in Brazil.

A major limitation of this study is its experimental nature, and the behavior of the prosthetic set in vivo may result in angular values different from those found, due to each patient's specific capsule-ligament anatomy. However, the use of simple low-cost software was consistent with other models in the literature and with the established technical standards, opening up the possibility of improving preoperative planning, making it more suitable for each patient, and improving the assessment of patients with prosthetic instability.

\section{CONCLUSION}

The computational method used in this study allowed us to conclude that the larger the femoral head, the greater the range of motion of the prosthetic system for the hip joint, with values within the technical standards recommended in Brazil. New clinical studies are required to compare the physical results obtained with the results found in this computational model.

AUTHOR'S CONTRIBUTION: Each author contributed individually and significantly to the development of this article. GGF: writing and statistical analysis; VR: project idealization and text revision; RB: computer simulations; ETT: project idealization and supervision of all stages of the project.

\section{REFERENCES}

1. Australian Orthopaedic Association, National Joint Replacement Registry. Hip, Knee \& Shoulder Arthroplasty: 2018 Annual Report. Adelaide; 2018.

2. Abdel MP, von Roth $P$, Jennings MT, Hanssen AD, Pagnano MW. What safe zone? The vast majority of dislocated THAs are within the Lewinnek safe zone for acetabular component position. Clin Orthop Relat Res. 2016;474(2):386-91.

3. Marchetti E, Krantz N, Berton C, Bocquet D, Fouilleron N, Migaud H, Girard J. Component impingement in total hip arthroplasty: frequency and risk factors. A continuous retrival analysis series of 416 cup. Orthop Traumatol Surg Res. 2011;97(2):127-33.

4. Pedersen DR, Callaghan JJ, Brown TD. Activity-dependence of the "safe zone" for impingement versus dislocation avoidance. Med Eng Phys. 2005;27(4):323-8.

5. 5. Peters CL, McPherson E, Jackson JD, Erickson JA. Reduction in early dislocation rate with large-diameter femoral heads in primary total hip arthroplasty. J Arthroplasty. 2007;22(6):140-4

6. McCarthy TF, Alipit V, Nevelos J, Elmallah RK, Mont MA. Acetabular cup anteversion and inclination in hip range of motion to impingement. J Arthroplasty. 2016;31(9):264-8.

7. Prabhakar PP, Chen Q, Schultz F, Lazennec JY, An KN. Automated range-of-motion device for total hip arthroplasty prosthesis. J Musculoskelet Res. 2006;10(3):151-5.

8. Brown TD, Callaghan JJ. Impingement in total hip replacement: mechanisms and consequences. Curr Orthop. 2008;22(6):376-91.
9. International Organization for Standardization. ISO 21535:2007 Non-active surgical implants - Joint replacement implants - Specific requirements for hip-joint replacement implants. ISO/TC 150/SC 4, Bone and joint replacements. Geneva; 2007.

10. Lewinnek GE, Lewis JL, Tarr R, Compere CL, Zimmerman JR. Dislocations after total hip-replacement arthroplasties. J Bone Joint Surg. 1978;60(2):217-20.

11. Associação Brasileira de Normas Técnicas. ABNT NBR ISO 21535:2018: Implantes cirúrgicos não ativos - Implantes para substituição de articulação - Requisitos específicos para implantes de substituição da articulação do quadril. Rio de Janeiro; 2018.

12. Kiguchi K, Yamashita A, Sasaki M, Ueno M, Kobayashi T, Mawatari M, Hotokebuchi T. Control of an Artificial-Hip-Joint Simulator to Evaluate Dislocation. In: Institute of Electrical and Electronics Engineers. Proceedings of International Conference on Control, Automation and Systems; 2008 Oct 14-17; Seoul, South Korea. Piscataway: IEEE; 2008. p. 1942-5.

13. Bunn A, Colwell CW Jr, D'Lima DD. Effect of head diameter on passive and active dynamic hip dislocation. J Orthop Res. 2014;32(11):1525-31.

14. McCarthy TF, Alipit V, Nevelos J, Elmallah RK, Mont MA. Acetabular cup anteversion and inclination in hip range of motion to impingement. J Arthroplasty. 2016;31(9):264-8.

15. Gu Y, Pierrepont J, Stambouzou C, Li Q, Baré J. A Preoperative Analytical Model for Patient-Specific Impingement Analysis in Total Hip Arthroplasty. Adv Orthop. 2019;2019:6293916. 